\title{
Depositional environments of the lower Permian Dwyka diamictite and Prince Albert shale inferred from the geochemistry of early diagenetic concretions, southwest Karoo Basin, South Africa
}

\author{
C.T. Herbert *, J.S. Compton \\ Department of Geological Sciences, University of Cape Town, Rondebosch 7700, South Africa
}

Received 9 December 2005; received in revised form 26 June 2006; accepted 28 June 2006

\begin{abstract}
The upper Dwyka and lower Ecca Groups in the Karoo Basin of South Africa document the climatic and palaeoenvironmental changes associated with the final Permo-Carboniferous deglaciation of the Gondwana supercontinent. The depositional environments of these groups have, until recently, been interpreted on the basis of sedimentological and palaeontological evidence. Here we use the geochemistry of early diagenetic concretions - septarian calcite concretions from the upper Dwyka Group and phosphatic chert concretions and beds from the lower Ecca Group - to infer the depositional environment of these rocks in the southwestern Karoo Basin. $\delta^{18} \mathrm{O}$ values ( 7.8 to $8.9 \%$ SMOW) suggest that the calcite concretions precipitated from a mixture of meteoric and glacial melt waters rather than Permian seawater. $\delta^{13} \mathrm{C}$ values $(-15$ to $-3 \%$ PDB) indicate that the carbon was derived from a mixture of craton-derived calcareous material and organic matter, bacterially degraded in the lower sulphatereduction to upper methanogenesis zones during early burial diagenesis. The rare-earth element (REE) patterns, Sr concentrations and ${ }^{87} \mathrm{Sr} /{ }^{86} \mathrm{Sr}$ ratios $(0.716-0.737)$ significantly greater than Permian seawater $(0.708)$, together also support the interpretation that calcite and phosphatic concretions formed in glacial, fresh water sediments.
\end{abstract}

(C) 2006 Elsevier B.V. All rights reserved.

Keywords: Permo-Carboniferous; Ice age; Rare earth elements; Stable isotopes; Sr isotopes; Gondwana; Concretions; Phosphorite; Karoo Basin

\section{Introduction}

The Late Palaeozoic was a time of major climatic change as the Gondwana ice sheets began their final retreat. At the peak of glaciation, the South Pole was located in southern Africa (Opdyke et al., 2001; Bumby and Guiraud, 2005) and ice sheets spread across approximately 70 million $\mathrm{km}^{2}$ of southern Gondwana (Visser, 1993). Widespread Permo-Carboniferous gla-

\footnotetext{
* Corresponding author. Fax: +27 216503783.

E-mail address: cherbert@geology.uct.ac.za (C.T. Herbert).
}

cial deposits in South America, Africa and Antarctica provide important evidence for the palaeoenvironments of Gondwana during the Late Palaeozoic. Of particular interest is the transition from full glacial to non-glacial conditions, preserved in the sediments of the upper Dwyka to lower Ecca Groups in the Karoo Basin of southern Africa (Catuneanu et al., 1998).

Depositional environments varied geographically in the Karoo Basin and ranged from marine to lacustrine for the Dwyka to lower Ecca Groups of southern Africa. Fossils from the Dwyka Group in the Warmbad Basin in southern Namibia (Fig. 1) indicate a marine depositional 


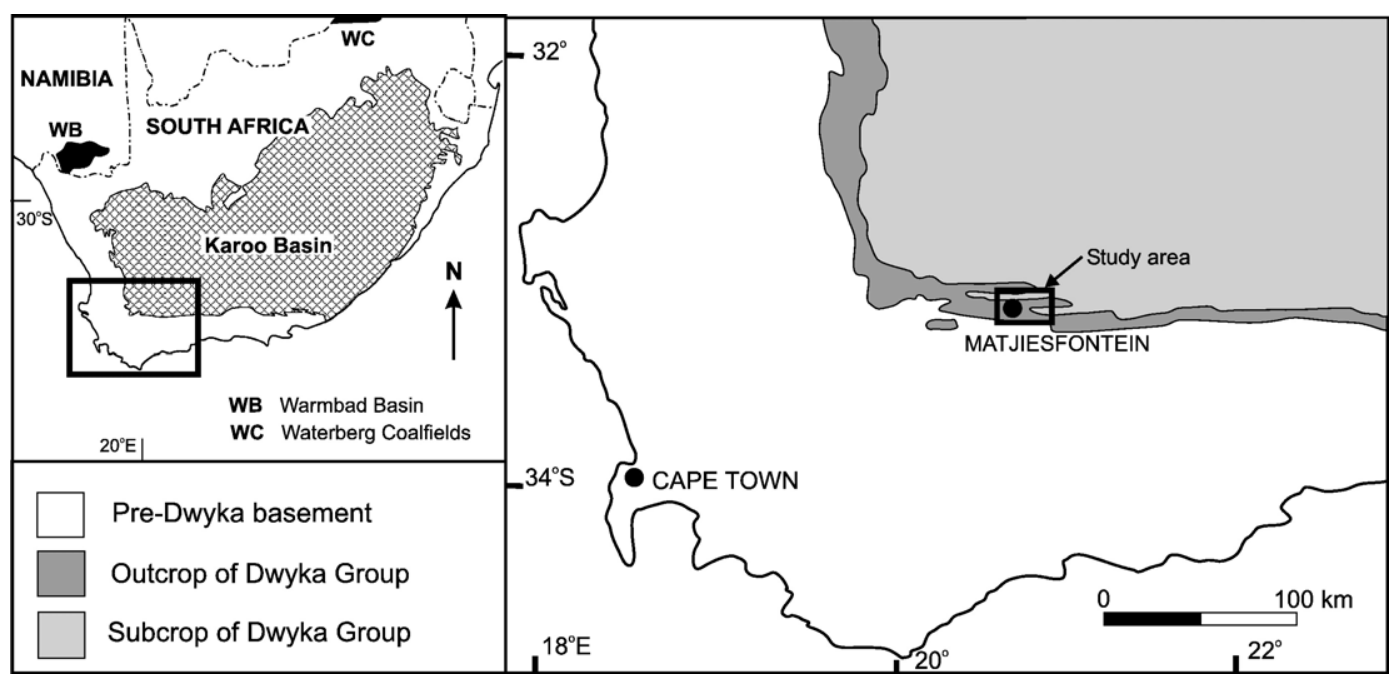

Fig. 1. Map showing the extent of the Dwyka Group in the southwest Karoo Basin, South Africa, and the location of the study area in the vicinity of Matjiesfontein after Visser and Loock (1987).

environment (Martin and Wilczewski, 1970). In the Main Karoo Basin, lower Ecca Group shales (Prince Albert Formation) are interpreted as marine basin or shelf deposits (Strydom, 1950; Oelofsen, 1986; Buhmann et al., 1989; Visser, 1991, 1994b; MacRae, 1999, p.135). However, in the eastern portion of the Main Karoo Basin, palaeontological evidence (Savage, 1970; Anderson, 1970) suggests a fresh water, periglacial environment for upper Dwyka deposits, and stable isotope analyses from sites along the northern and southern margins of the basin (Faure and Cole, 1999) indicate a brackish to fresh water depositional environment for the lower Ecca Group.

Palaeoenvironmental studies in the southwestern portion of the Main Karoo Basin have relied mainly on sedimentological features because fossil evidence is limited (McLachlan and Anderson, 1973). In contrast to rare fossils, hard, resistant concretions weather conspicuously from outcrops of the upper Dwyka diamictites and Prince Albert Formation in the southwestern Main Karoo Basin. In this paper, the geochemistry of concretions collected from the study area (Fig. 1) across the Dwyka-Ecca boundary is argued to indicate that the concretions formed during early diagenesis in a glacial melt water lake depositional environment.

\section{Geological setting}

The depositional history of the Main Karoo retro-arc foreland basin, recorded in the Karoo Supergroup, spans from the Late Carboniferous to the Middle Jurassic
(Catuneanu et al., 2002). Situated on the craton side of the Cape Fold Belt, a north verging fold and thrust belt created by subduction along the palaeopacific margin (Daly et al., 1992), the Karoo Supergroup attains a maximum thickness of $6-8 \mathrm{~km}$ in the south (Rubidge, 1995). Little is known about the degree of metamorphism of the Karoo Supergroup, however rocks of the Cape Fold Belt have undergone, at most, lower greenschist grade (approximately $200{ }^{\circ} \mathrm{C}$ ) metamorphism (de Swart and Rowsell, 1974).

The glaciogenic Dwyka Group constitutes the oldest rocks of the Karoo Supergroup (Figs. 1 and 2). Glacial sedimentation dominated from the Late Carboniferous to Early Permian (Bangert et al., 1999; Veevers and Powell, 1987; Visser, 1989, 1990, 1993). Visser (1986) divided the Dwyka Group into two facies: a valleyhighland facies that consists of a heterolithic sequence of variable thickness, found along the northern margin of the Karoo Basin and in the Kalahari Basin in Namibia; and a shelf facies that consists of massive and stratified diamictites with distantly derived clasts and a more uniform thickness, found in the western and southern Karoo Basin. In the southern Karoo Basin, four deglaciation sequences are identified (DS1-DS4) each consisting of a basal zone of massive diamictite ("c" unit) that, in the younger sequences, is capped by a stratified terminal zone ("f" unit) (Fig. 2) (Theron and Blignault, 1975). The youngest of the Dwyka Group units (DS 4c and f) consist of clast-poor diamictite with subordinate mudstone that is interpreted to be dense proximal rain-out deposits from melting icebergs, 


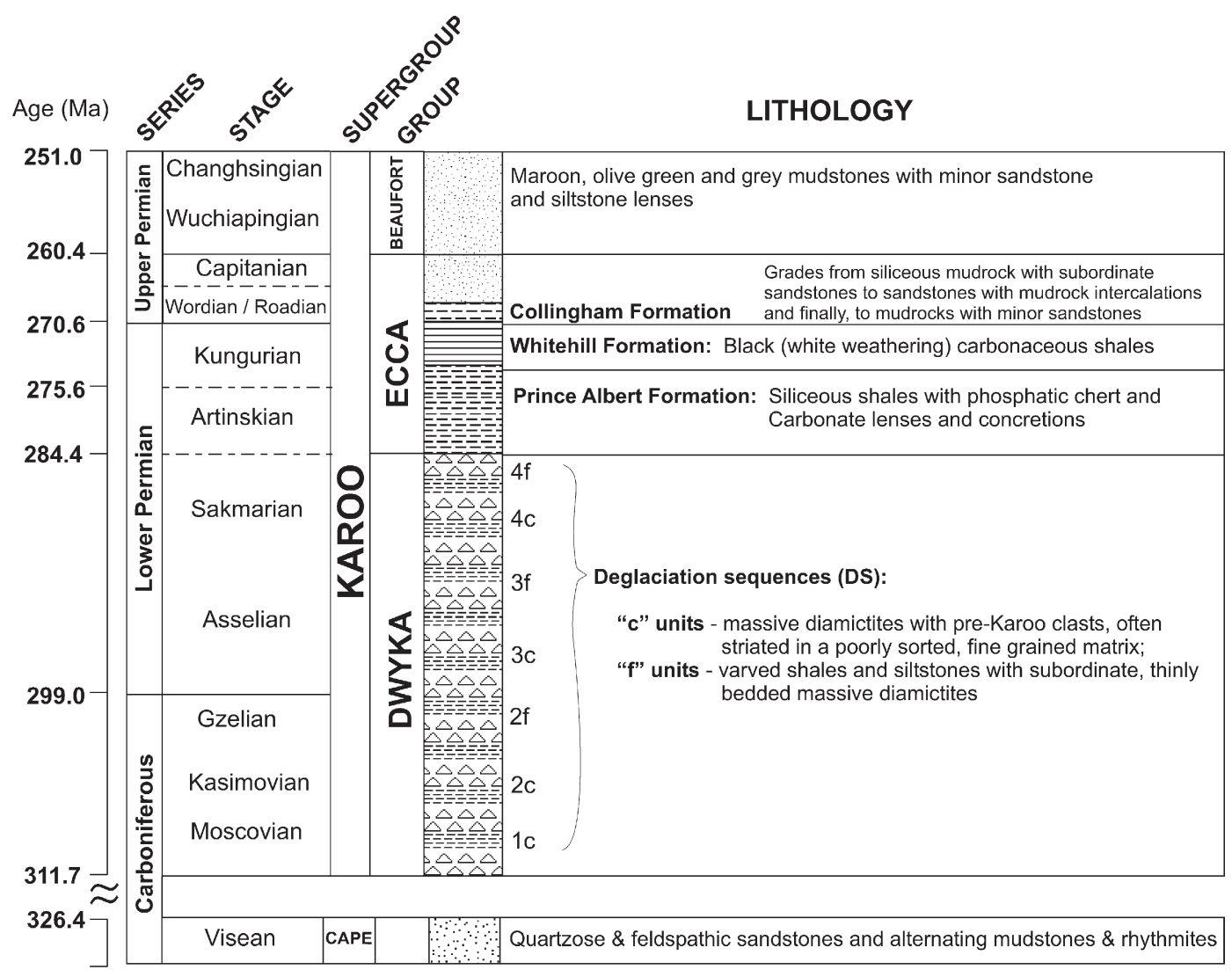

Fig. 2. Stratigraphic column of the lowermost units in the Karoo Supergroup after Catuneanu et al. (1998) and Gradstein et al. (2004).

locally modified by sediment gravity flows (Visser and Loock, 1987; Visser, 1989, 1994a). The DS4 diamictites have higher carbonate contents than the older Dwyka diamictites and include a number of carbonate concretions. Overlying the Dwyka Group diamictites in the southwestern Main Karoo Basin are the cherty and phosphatic siltstone and mudstone beds of the Prince Albert Formation (Fig. 2). The Prince Albert Formation was deposited as syn- to post-glacial suspension fall-out and flocculation of fines from large inflows of sedimentladen water (Domack, 1983; Smith and Ashley, 1985), with some input by periodic turbidites and mud flows of semi-consolidated sediments (Tankard et al., 1982; Visser, 1991).

\section{Methods}

Samples were collected north of the town of Matjiesfontein (Fig. 1) from two outcrops (Sites 1 and 2; Fig. 3). The Prince Albert Formation was sampled at both sites, while the upper diamictite (DS $4 \mathrm{c}-4 \mathrm{f}$ units) of the Dwyka Group was sampled at Site
1 and the lower diamictite (DS 4c units) was sampled at Site 2 (Fig. 4). Thin section petrography, X-ray diffraction (XRD) and scanning electron microscopy (SEM) were used to determine the mineralogy and textures of the different lithologic units. The calcite and carbonate-fluorapatite (CFA) concretion cements were preferentially dissolved in doubly distilled $5 \mathrm{M}$ acetic acid and passed through a $0.22 \mu \mathrm{m}$ membrane filter for trace element and strontium isotope analysis (Tables 1 and 2) by inductively coupled plasma mass spectrometry (ICP-MS). Samples BD and Pn (A) underwent total dissolution ( $\mathrm{HF}: \mathrm{HNO}_{3}$ of 4:1). The rare-earth element (REE) data are normalised to PostArchean average Australian sedimentary rocks (PAAS) (McLennan, 1989). Drilled, powdered samples from the centre to the rim of split calcite concretions were dried for at least $48 \mathrm{~h}$ at $50{ }^{\circ} \mathrm{C}$ and reacted offline with $100 \%$ phosphoric acid at $25{ }^{\circ} \mathrm{C}$ for a minimum of $4 \mathrm{~h}$. Samples were run on a MAT252 mass spectrometer and corrected using the $\mathrm{CO}_{2}$-calcite fractionation factor of 1.01025 (Table 3). The differences in duplicate analyses of the "in-house" standard Namaqualand 

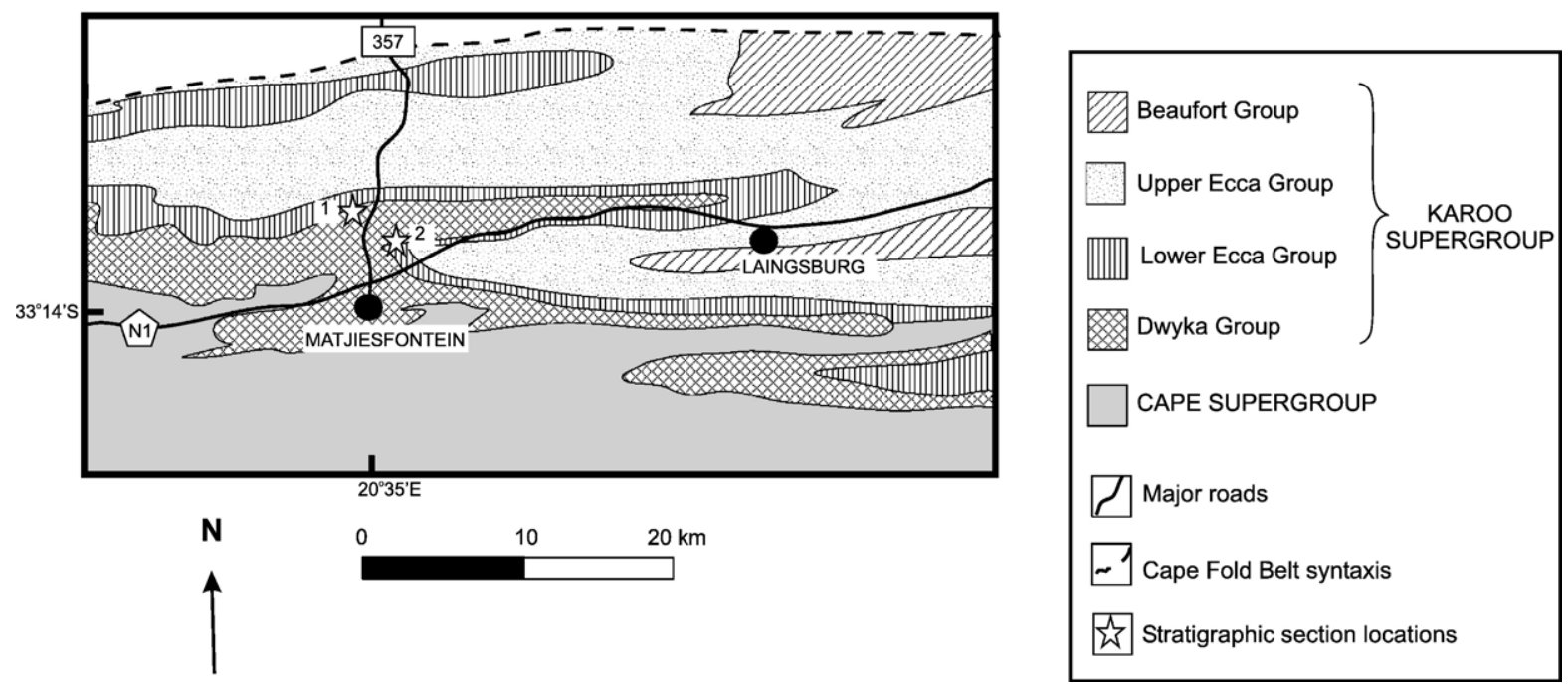

Fig. 3. Regional geology of the study area after Cole et al. (1990).

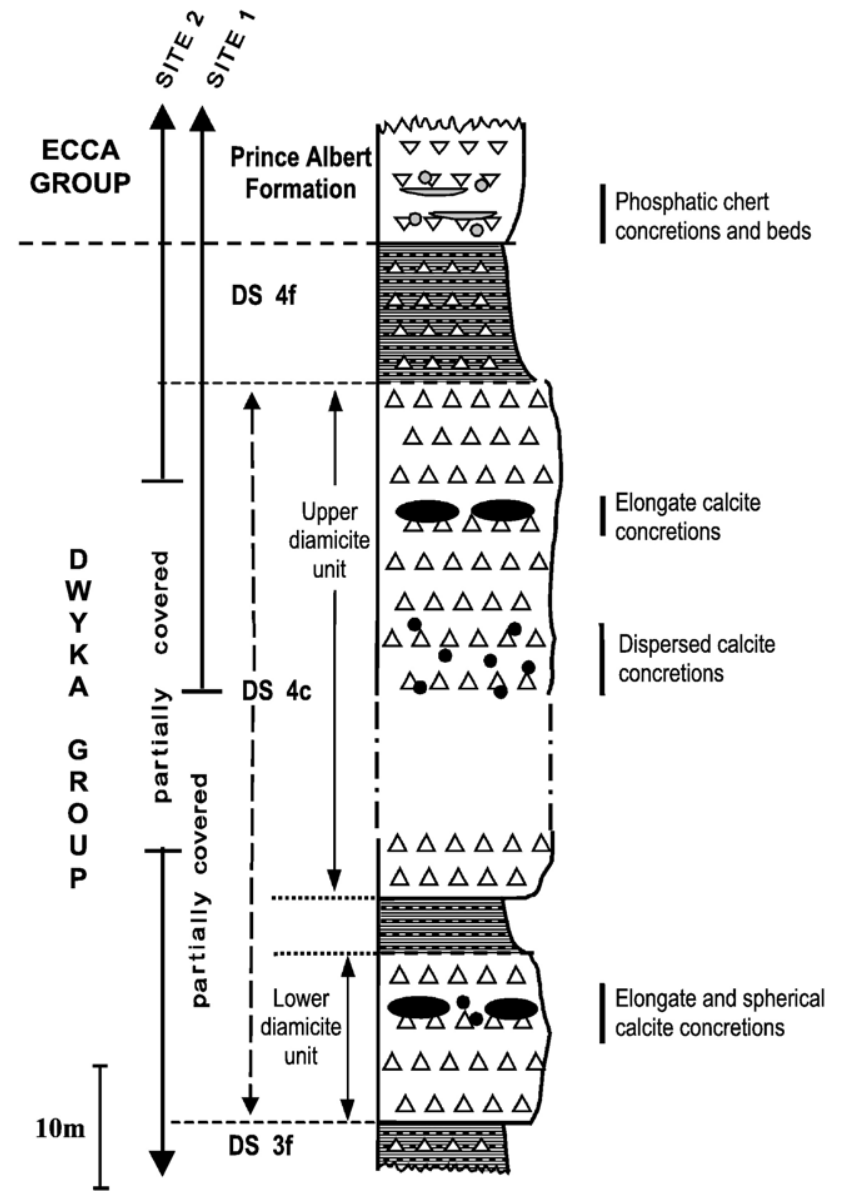

\section{SAMPLES}

L1 and Pn (concretions)

B4a and $\mathrm{Pb}[0.717 \pm 0.003]$ (beds)

$2 C[0.716 \pm 0.002]$

5C $[0.717 \pm 0.003]$

$\nabla \nabla$ Tuffs and cherty siltstones

Laminated siltstones and

minor diamictites

$\Delta \Delta$ Massive diamictite

Laminated mudstones

and siltstones

Elongate calcite concretions

- Spherical calcite concretions

으 Phosphatic concretions

Phosphatic beds / lenses
BD $[0.737 \pm 0.002]$ (elongate)

CN $[0.716 \pm 0.003]$ and 4B (spherical)

F3b (host rock calcite cement)

Fig. 4. Stratigraphic column showing the position of the sampled calcite concretions from the DS 4c unit, Dwyka Group, and phosphatic concretions and beds from the overlying Prince Albert Formation, Ecca Group. The lower part of the unit is from Site 2 and the upper part is from Site 1 on the regional geology map (Fig. 3). Values enclosed in square brackets are the ${ }^{87} \mathrm{Sr} /{ }^{86} \mathrm{Sr}$ ratios. 
Table 1

Rare-earth element, barium, rubidium and strontium concentrations (in ppm) of calcite cements from concretions from the Dwyka DS 4c unit and of carbonate-fluorapatite (CFA) of phosphatic chert concretions and beds from the lower Prince Albert Formation

\begin{tabular}{|c|c|c|c|c|c|c|c|c|c|c|c|c|c|c|c|c|c|c|}
\hline & & $\mathrm{La}$ & $\mathrm{Ce}$ & $\operatorname{Pr}$ & $\mathrm{Nd}$ & $\mathrm{Sm}$ & $\mathrm{Eu}$ & $\mathrm{Gd}$ & $\mathrm{Tb}$ & Dy & Ho & Er & $\mathrm{Tm}$ & $\mathrm{Yb}$ & $\mathrm{Lu}$ & $\mathrm{Ba}$ & $\mathrm{Rb}$ & $\mathrm{Sr}$ \\
\hline \multicolumn{19}{|c|}{ Prince Albert Formation, Ecca Group } \\
\hline \multirow{2}{*}{$\begin{array}{l}\text { CFA from phosphatic } \\
\text { chert concretions }\end{array}$} & $\operatorname{Pn}(A)^{a}$ & 80.4 & 186.7 & 40.2 & 221.8 & 93.1 & 168.7 & 130.1 & 16.2 & 65.0 & 10.3 & 18.0 & 1.9 & 7.9 & 1.1 & & 10.5 & 2353 \\
\hline & Pn (B) & 17.0 & 36.7 & 7.3 & 43.7 & 17.2 & 34.2 & 25.7 & 3.0 & 12.2 & 2.1 & 3.8 & 0.4 & 1.7 & 0.3 & & 2.8 & 1415 \\
\hline \multirow{4}{*}{$\begin{array}{l}\text { CFA from phosphatic } \\
\text { chert beds }\end{array}$} & $\mathrm{B} 4 \mathrm{a}$ & 13.2 & 21.7 & 3.6 & 20.4 & 7.6 & 11.9 & 11.6 & 1.3 & 5.6 & 1.0 & 2.0 & 0.2 & 1.1 & 0.2 & & 7.2 & 1612 \\
\hline & $\mathrm{Pb}(\mathrm{A})$ & 20.9 & 39.1 & 7.2 & 41.3 & 14.8 & 18.8 & 23.9 & 2.6 & 11.1 & 2.1 & 4.0 & 0.4 & 1.8 & 0.3 & & 2.2 & 1172 \\
\hline & $\mathrm{Pb}(\mathrm{C})$ & 21.7 & 50.0 & 8.5 & 48.6 & 18.6 & 23.1 & 29.1 & 3.2 & 14.1 & 2.2 & 4.4 & 0.5 & 2.1 & 0.3 & 187.4 & 2.1 & 1029 \\
\hline & L1 & 7.6 & 19.3 & 3.4 & 18.1 & 6.4 & 4.9 & 8.2 & 1.0 & 4.5 & 0.8 & 1.5 & 0.2 & 0.8 & 0.1 & & 7.3 & 223 \\
\hline \multicolumn{19}{|c|}{ DS4c unit, Dwyka Group } \\
\hline \multirow{4}{*}{$\begin{array}{l}\text { Calcite cement } \\
\text { from concretions }\end{array}$} & $\mathrm{BD}^{\mathrm{a}}$ & 37.4 & 60.8 & 7.4 & 29.9 & 5.2 & 1.1 & 5.0 & 0.6 & 3.4 & 0.7 & 2.0 & 0.3 & 1.8 & 0.3 & 283.2 & 49.8 & 449 \\
\hline & $2 \mathrm{C}$ & 37.4 & 79.6 & 9.7 & 41.8 & 11.5 & 3.0 & 15.1 & 2.5 & 14.6 & 2.9 & 7.1 & 0.9 & 5.5 & 0.8 & 79.7 & 8.1 & 609 \\
\hline & $5 \mathrm{C}$ & 21.2 & 42.0 & 5.1 & 22.5 & 6.6 & 2.1 & 9.1 & 1.5 & 9.2 & 1.9 & 5.0 & 0.7 & 4.7 & 0.7 & 74.6 & 9.8 & 515 \\
\hline & $\mathrm{CN}$ & 51.6 & 53.6 & 9.2 & 38.2 & 5.7 & 0.9 & 5.4 & 0.6 & 2.9 & 0.7 & 1.8 & 0.3 & 1.7 & 0.3 & 53.5 & 5.9 & 566 \\
\hline $\begin{array}{l}\text { Disseminated calcite } \\
\text { in host diamictite }\end{array}$ & $\mathrm{F} 3 \mathrm{~b}$ & 22.0 & 26.6 & 5.3 & 19.8 & 2.7 & 0.4 & 2.0 & 0.2 & 1.1 & 0.2 & 0.7 & 0.1 & 0.7 & 0.1 & 122.5 & 19.6 & 73 \\
\hline
\end{tabular}

${ }^{a}$ underwent total digestion.

Marble run in the same batch were $0.07 \%$ for $\delta^{18} \mathrm{O}$ and $0.06 \%$ for $\delta^{13} \mathrm{C}$.

\section{Results}

\subsection{Stratigraphy}

Spheroidal and elongate concretions are distinctive features of the DS 4c unit (Fig. 4), occurring along specific stratigraphic horizons. In the study area, a lower massive diamictite of the DS 4c unit grades upwards into a $4 \mathrm{~m}$ thick laminated silty shale that is in sharp contact with an

Table 2

The ${ }^{87} \mathrm{Sr} /{ }^{86} \mathrm{Sr}$ ratios determined by ICP-MS for the Dwyka DS 4c unit calcite cements and for carbonate-fluorapatite (CFA) from the lower Prince Albert Formation phosphatic chert samples

\begin{tabular}{llll}
\hline & & \multicolumn{2}{l}{ ICP-MS } \\
\cline { 3 - 4 } & & ${ }^{87} \mathrm{Sr} /{ }^{86} \mathrm{Sr}$ & $+/-$ \\
\hline $\begin{array}{l}\text { Holocene oyster shell } \\
\quad \text { from Langebaan Lagoon }\end{array}$ & & $0.709^{\mathrm{a}}$ & 0.002 \\
$\begin{array}{l}\text { Prince Albert Formation, Ecca Group } \\
\text { CFA from phosphatic chert concretions }\end{array}$ & $\mathrm{Pn}(\mathrm{D})$ & 0.722 & 0.003 \\
CFA from phosphatic chert beds & $\mathrm{Pb}(\mathrm{C})$ & 0.717 & 0.003 \\
& & & \\
DS 4c unit, Dwyka Group & & & \\
Calcite cement from concretions & $\mathrm{BD}{ }^{\mathrm{b}}$ & 0.737 & 0.002 \\
& $2 \mathrm{C}$ & 0.716 & 0.002 \\
& $5 \mathrm{C}$ & 0.717 & 0.003 \\
& $\mathrm{CN}$ & 0.716 & 0.003 \\
\hline
\end{tabular}

The analysis of a modern oyster shell is shown for comparison.

${ }^{a}$ Within error of ratio of modern seawater (0.7091).

b Underwent total digestion. overlying upper massive diamictite (Fig. 4). The spherical and elongate calcite concretions of the lower diamictite unit occur together along a single stratigraphic horizon. The spherical calcite concretions of the upper diamictite unit are spread randomly over a $10 \mathrm{~m}$ thick interval approximately $15 \mathrm{~m}$ below a stratigraphic horizon of elongate calcite concretions. The upper diamictite grades upwards into the highly friable and thinly bedded grey mudstones of the DS $4 \mathrm{f}$ unit that is overlain by the Prince Albert Formation. The Prince Albert Formation is divided into two units in the study area, a lower chestnut-brown unit and an upper blackish-brown unit. The lower unit contains pebble to small boulder sized concretions and beds of phosphatic, cherty siltstone (Visser, 1994a).

\subsection{Petrography}

Calcite concretions in the DS 4c unit are near-spherical and up to $20 \mathrm{~cm}$ in diameter (Fig. 5) or lens-shaped and up to $30 \mathrm{~cm}$ thick and $5 \mathrm{~m}$ long (Fig. 6). No deformational sedimentary structures were observed between the concretions and the surrounding massive diamictite. The concretions consist of 41 to $60 \mathrm{wt} . \%$ calcite cement. The calcite cement tends to decrease slightly and the detrital grain content increases from the centre to the rim of the concretions. Concretions have significantly higher calcite content than the host diamictite (10-15 wt.\% calcite). The concretions consist of sub-angular to angular sand-sized grains of quartz, plagioclase and orthoclase feldspar and various lithic fragments including quartzite, schist and gneiss, in a muddy matrix cemented with microcrystalline calcite. No detrital calcareous grains or replacement of 
Table 3

Stable isotope $\left(\delta^{3} \mathrm{C}\right.$ and $\left.\delta^{18} \mathrm{O}\right)$ data for the calcite matrix cements and vein calcite in the Dwyka DS 4c concretions

\begin{tabular}{|c|c|c|c|c|c|}
\hline & Sample & & $\delta^{13} \mathrm{C}(\mathrm{PDB})$ & $\delta^{18} \mathrm{O}(\mathrm{SMOW})$ & $\delta^{18} \mathrm{O}(\mathrm{PDB})$ \\
\hline \multicolumn{6}{|c|}{ Upper diamictite unit of DS4c } \\
\hline \multirow[t]{4}{*}{ Lenticular bed } & $2 \mathrm{C}-1$ & Top & -10.5 & 8.0 & -22.2 \\
\hline & $2 \mathrm{C}-2$ & 1 & -9.2 & 8.3 & -21.9 \\
\hline & $2 \mathrm{C}-3$ & $\downarrow$ & -8.7 & 8.5 & -21.7 \\
\hline & $2 \mathrm{C}-4$ & Bottom & -8.6 & 8.7 & -21.5 \\
\hline \multirow[t]{4}{*}{ Spherical concretion } & $5 \mathrm{C}-1$ & Centre & -9.7 & 8.3 & -21.9 \\
\hline & $5 \mathrm{C}-2$ & 1 & -10.9 & 8.1 & -22.0 \\
\hline & $5 \mathrm{C}-3$ & $\downarrow$ & -9.8 & 8.1 & -22.1 \\
\hline & $5 \mathrm{C}-4$ & Rim & -2.9 & 7.9 & -22.2 \\
\hline Vein calcite & $5 \mathrm{~A}-1$ & & -8.4 & 6.7 & -23.4 \\
\hline \multicolumn{6}{|c|}{ Lower diamictite unit of DS4c } \\
\hline \multirow[t]{4}{*}{ Lenticular bed } & BD-1 & Centre & -15.2 & 8.3 & -21.9 \\
\hline & BD-2 & & -15.2 & 8.3 & -21.9 \\
\hline & BD-3 & $\downarrow$ & -15.5 & 8.0 & -22.1 \\
\hline & BD-4 & Rim & -15.6 & 8.2 & -22.0 \\
\hline \multirow[t]{7}{*}{ Spherical concretions } & 4B-3 & Centre & -14.8 & 8.3 & -21.9 \\
\hline & $4 B-2$ & $\downarrow$ & -14.9 & 8.4 & -21.8 \\
\hline & 4B-1 & Rim & -14.6 & 8.9 & -21.3 \\
\hline & $\mathrm{CN}-1$ & Centre & -15.4 & 7.8 & -22.4 \\
\hline & $\mathrm{CN}-2$ & & -15.1 & 7.9 & -22.3 \\
\hline & $\mathrm{CN}-3$ & $\downarrow$ & -14.8 & 8.3 & -21.9 \\
\hline & $\mathrm{CN}-4$ & Rim & -15.1 & 8.4 & -21.8 \\
\hline
\end{tabular}

detrital grains by calcite was observed, but some larger grains have micritic coatings. Some concretions have a micritic calcite-rich core (Fig. 7). Spherical concretions commonly have septarian calcite-filled veins that radiate outward from the centre and pinch out before reaching the concretion rim (Fig. 7). The septarian veins are filled with at least two generations of calcite, an initial micritic calcite with abundant brown iron-rich inclusions and a final sparry calcite.

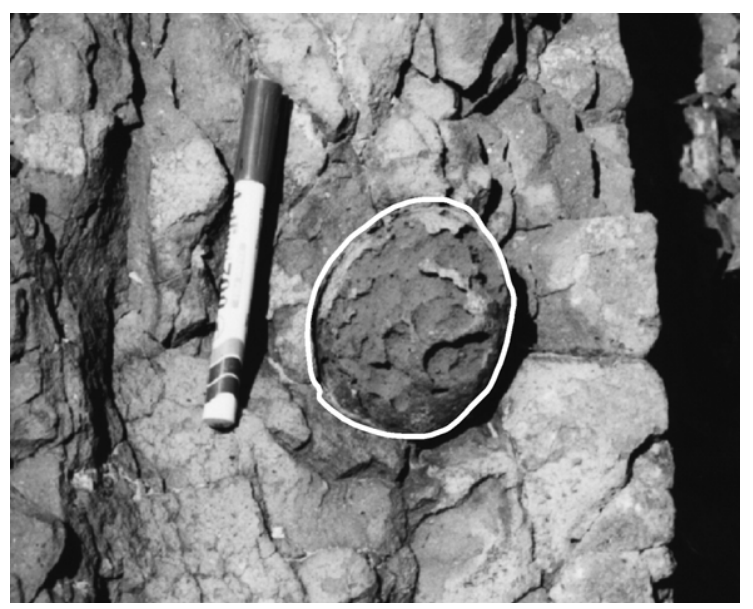

Fig. 5. A typical small, spherical calcareous concretion (enclosed by the white line) exposed on a weathered outcrop surface of the lower DS $4 \mathrm{c}$ diamictite unit at Site 2 (pen for scale, with lid showing way up).
Phosphatic chert concretions are generally stratabound and ellipsoidal and up to $30 \mathrm{~cm}$ in diameter (Fig. 8). The beds are usually less than $15 \mathrm{~cm}$ thick and are either lenticular or planar. The black, fresh phosphaticrich rocks develop blue-white weathered surfaces. The phosphatic chert concretions and beds consist mainly of quartz silt cemented by micro- to cryptocrystalline carbonate-fluorapatite (CFA) and quartz (Fig. 9). The concretions tend to have more CFA-rich centres. Some samples exhibit a dendritic pattern of CFA precipitation, radiating outward from the concretion core. These samples also include sand-sized CFA-enriched concretions that surround the outer edges of the concretions.

\subsection{Geochemistry}

The $\delta^{18} \mathrm{O}$ values of all calcite concretion matrix cements (Table 3) are similar, ranging from 7.8 to $8.9 \%$ (SMOW) (Fig. 10). However, two distinct $\delta^{18} \mathrm{O}$ trends are observed within the concretions (Fig. 11). Calcite concretions in the lower DS 4c diamictite unit exhibit an increase in $\delta^{18} \mathrm{O}$ values from centre to rim. In contrast, $\delta^{18} \mathrm{O}$ values of a spherical concretion from the upper diamictite unit decrease from centre to rim (sample 5C) and from bottom to top in an elongate concretion (sample 2C). Calcite $\delta^{13} \mathrm{C}$ values of concretions from the lower DS $4 \mathrm{c}$ diamictite unit (samples $\mathrm{BD}, \mathrm{CN}$ and $4 \mathrm{~B}$ ) range from -15.6 to $-14.6 \%$ (PDB), whereas calcite $\delta^{13} \mathrm{C}$ 


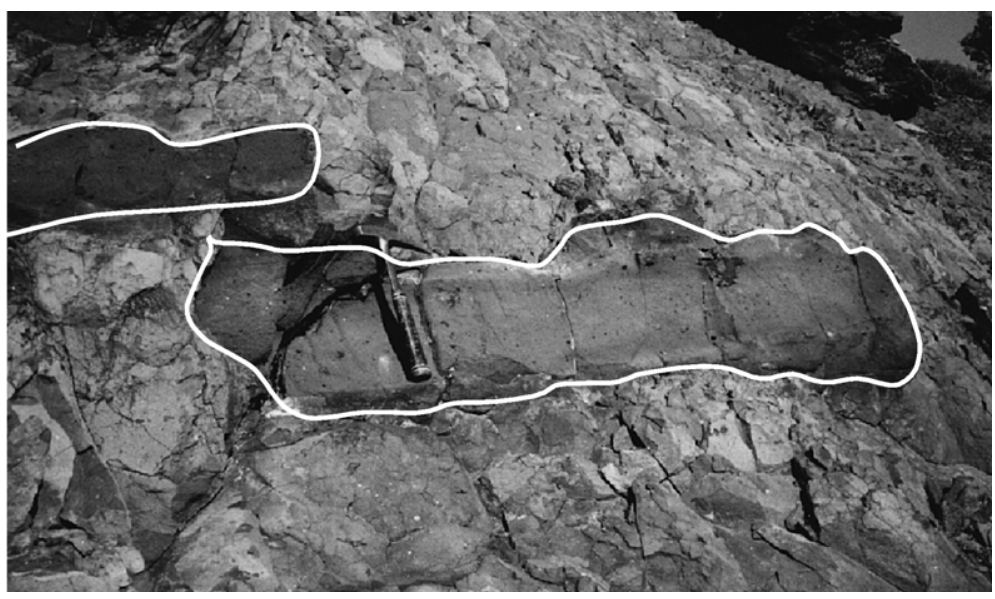

Fig. 6. Elongate calcareous concretions (enclosed by white lines) exposed on a weathered outcrop surface of the lower DS 4c diamictite unit at Site 2 (rock hammer for scale, with hammer head showing way up).

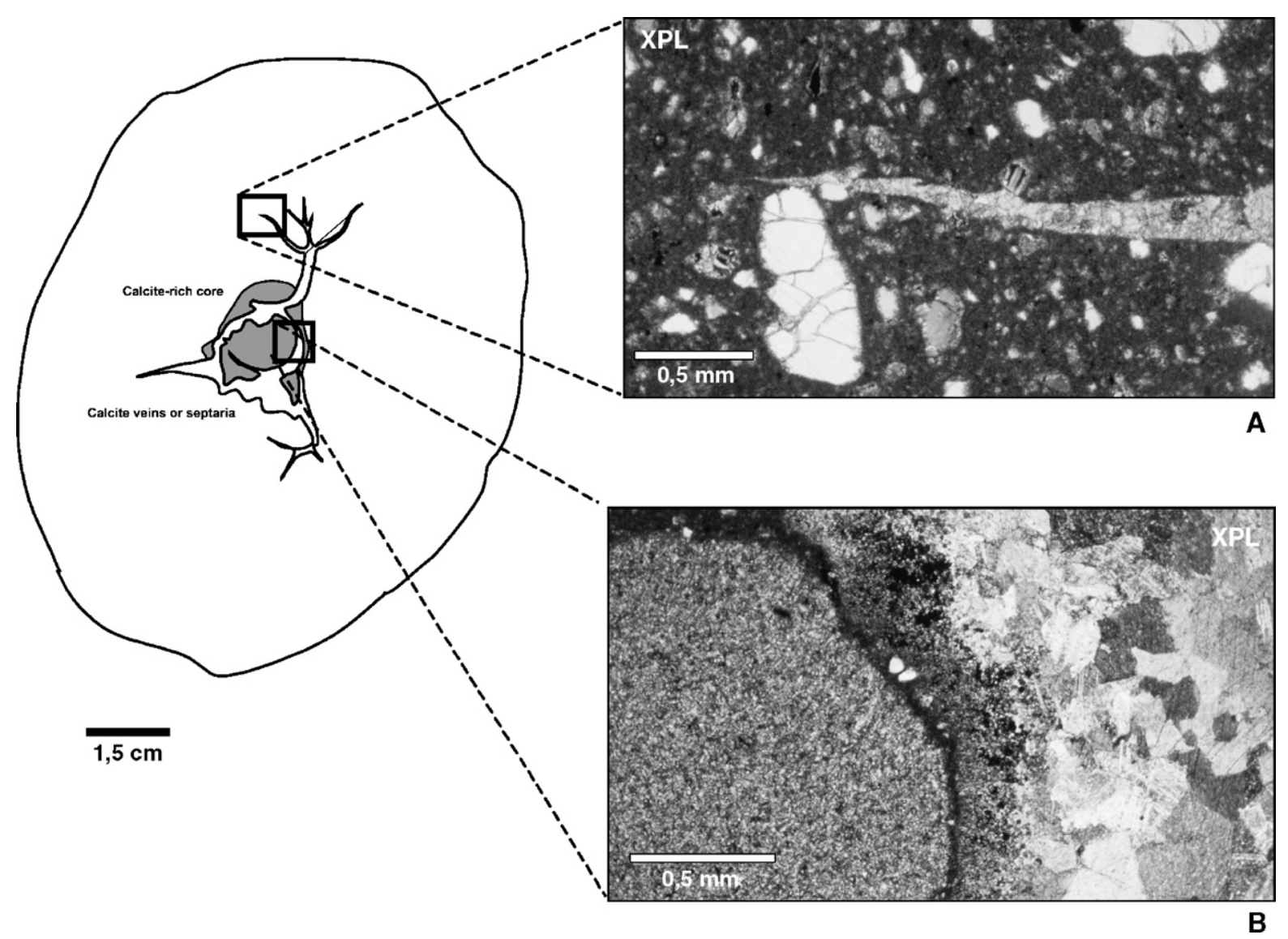

Fig. 7. A sketch of the interior section of a typical Dwyka DS $4 \mathrm{c}$ calcite concretion showing the septarian veins radiating out from the centre. Photomicrograph (A) shows the termination of the calcite vein that pinches out before reaching the rim of the concretion. Photomicrograph (B) shows the edge of the fine-grained calcite-rich core at the centre of the concretion, adjacent to which a calcite vein grades from an inclusion-rich micrite to sparry calcite. (XPL: Crossed polarized light). 


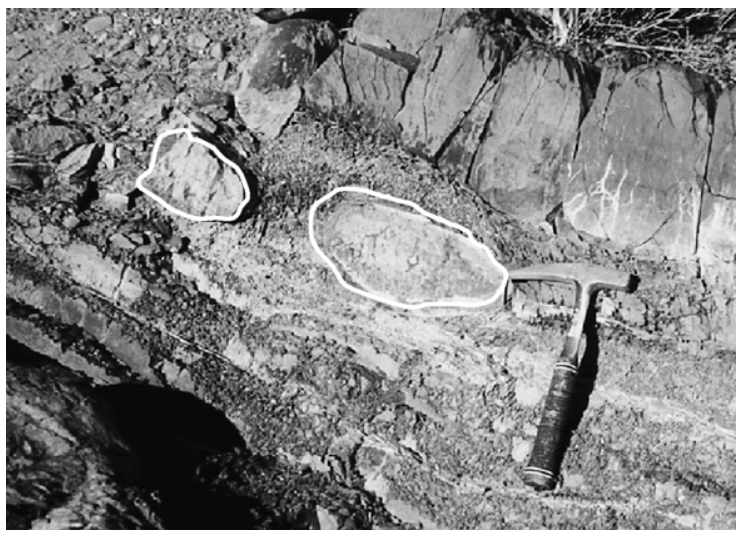

Fig. 8. Two ellipsoidal phosphatic chert concretions in the Prince Albert Formation (enclosed by white lines) exposed on a weathered outcrop at Site 2. The concretions occur along the same bedding plane and are flattened parallel to bedding (rock hammer for scale).

values of concretions from the upper diamictite unit range from -10.9 to $-2.9 \%$ (PDB) (Fig. 10). The three spherical concretions exhibit trends of increasing $\delta^{13} \mathrm{C}$ values toward the rim, whereas the $\delta^{13} \mathrm{C}$ values decrease slightly in the elongate concretions from centre to rim (sample $\mathrm{BD}$ ), and from bottom to top in sample 2C (Fig. 11). Sparry vein calcite from septaria in concretion $5 \mathrm{C}$ (sample $5 \mathrm{~A}-1$ ) has a $\delta^{18} \mathrm{O}$ value of $6.7 \%$ (SMOW) that is less than the surrounding calcite cements, and a $\delta^{13} \mathrm{C}$ value of $-8.4 \%$ o (PDB) that is within the range of values for calcite concretions in the upper diamictite unit (Fig. 10).

The REE patterns of calcite cements from the lowermost Dwyka Group DS 4c diamictite unit (samples BD, $\mathrm{CN}$ and F3b) exhibit fairly strong negative cerium anomalies and are enriched in the light rare-earth elements (LREE) (Fig. 12a). Samples CN and F3b have slight negative europium anomalies. The REE patterns of calcite cement from the upper diamictite of the Dwyka Group DS 4c unit (samples 5C and 2C) show LREE depletion and no appreciable Ce anomaly (Fig. 12a). Calcite concretions have $\mathrm{Sr}$ concentrations that range from 449 to $609 \mathrm{ppm}$, and ${ }^{87} \mathrm{Sr} /{ }^{86} \mathrm{Sr}$ ratios that range from 0.716 to 0.737 (Table 2). The $\mathrm{Sr}$ concentration of disseminated calcite cement in the host diamictite (DS 4c) is $73 \mathrm{ppm}$. Phosphatic cements from two nodules and two beds of the Prince Albert Formation were analysed by ICP-MS (Table 1). The REE patterns of Prince Albert Formation phosphatic chert concretions (samples Pn and L1) and phosphatic beds (samples $\mathrm{Pb}$ and B4a) exhibit middle REE enrichment, large positive $\mathrm{Eu}$ anomalies and slight negative $\mathrm{Ce}$ anomalies (Fig. 12b). Sample Pn (A), which underwent total digestion, shows overall higher REE concentrations. Phosphatic chert concretions have $\mathrm{Sr}$ concentrations that range from 223 to $2353 \mathrm{ppm}$ and ${ }^{87} \mathrm{Sr} /{ }^{86} \mathrm{Sr}$ ratios of 0.717 and 0.722 (Table 2).

\section{Discussion}

\subsection{Origin and depositional environment of the concretions}

The $\delta^{18} \mathrm{O}$ values of calcite concretions from both the upper and lower DS 4c diamictites (Fig. 10) are comparable to concretions from the upper Prince Albert Formation (Faure and Cole, 1999) and to concretions from the Permo-Carboniferous glacial deposits of the Talchir Formation in India (Bhattacharya et al., 2002). The $\delta^{18} \mathrm{O}$ values for all of these calcite concretions are much lower than the average $\delta^{18} \mathrm{O}$ value of abiotic lower Permian

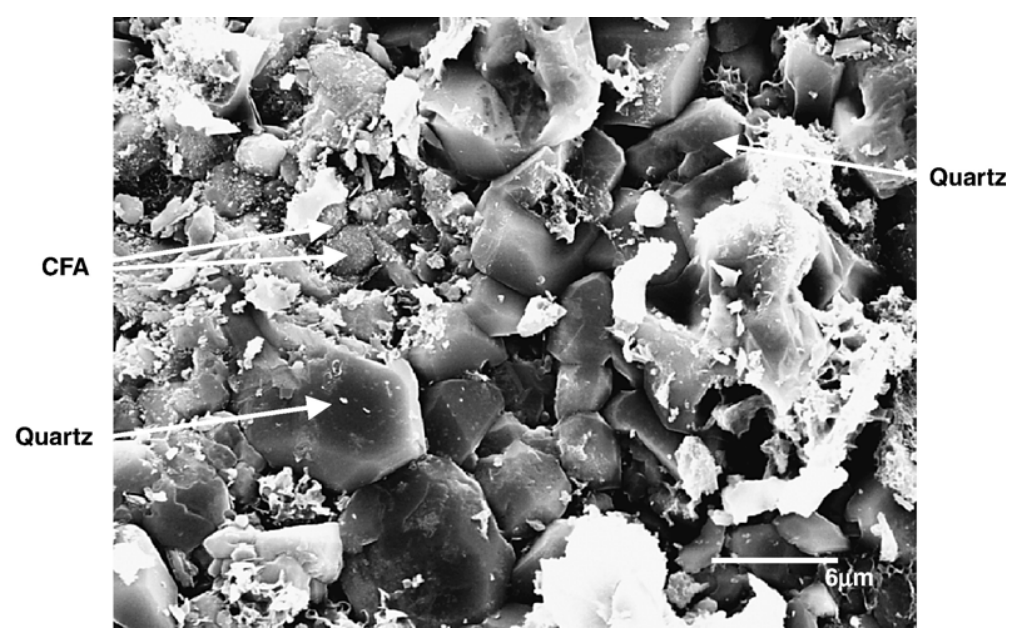

Fig. 9. SEM image showing the intergrowth of microcrystalline quartz and carbonate-fluorapatite in a phosphatic chert nodule (sample L1). 


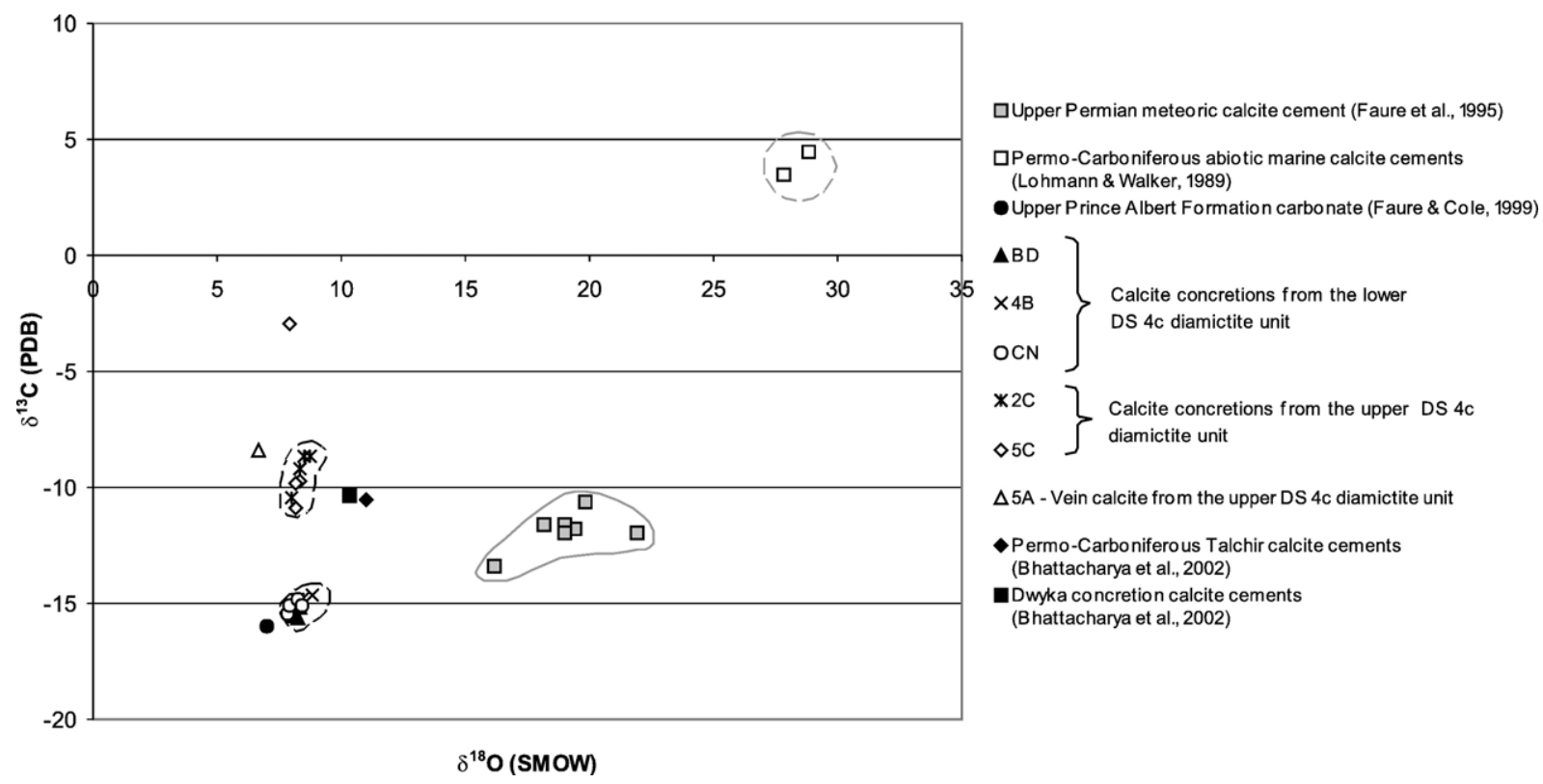

Fig. 10. $\delta^{13} \mathrm{C}$ plotted against $\delta^{18} \mathrm{O}$ for the Dwyka DS $4 \mathrm{c}$ calcite cements and calcite vein (enclosed in dashed black lines), as well as the calcite from the upper Prince Albert Formation (Faure and Cole, 1999) (solid circle). Upper Permian calcite cements from lenses in the Waterberg Coalfield (Fig. 1), which are interpreted to have precipitated from meteoric water, are enclosed in a solid grey line (Faure et al., 1995). Permo-Carboniferous abiotic marine calcite cements (Lohmann and Walker, 1989) are enclosed in a dashed grey line. Also shown are the mean isotopic values obtained by Bhattacharya et al. (2002) for Permo-Carboniferous calcite concretions from the Talchir sediments in India (solid square) and for four Dwyka Group samples (solid diamond).

marine calcite cements (Lohmann and Walker, 1989). The isotopic composition of the water from which the DS 4c concretions precipitated is estimated to be $-26.5 \%$ (SMOW) using the equation of Anderson and Arthur (1983) and assuming a palaeotemperature of $0{ }^{\circ} \mathrm{C}$ and a mean $\delta^{18} \mathrm{O}$ value for the DS $4 \mathrm{c}$ cements of $8.2 \%$ (SMOW) (-22\%o PDB). Calcite cements of upper Permian concretions from the Waterberg Coalfield in the northern Main Karoo Basin have $\delta^{18} \mathrm{O}$ values of between 16.2 and $21.9 \%$ (SMOW) and were shown by Faure et al. (1995) to have precipitated from meteoric water with a $\delta^{18} \mathrm{O}$ value of approximately $-13 \%$ (SMOW). However, meteoric waters would have had $\delta^{18} \mathrm{O}$ values more depleted than $-13 \%$ (SMOW) during the early Permian when the Karoo Basin was at higher latitudes than during the late Permian. The $\delta^{18} \mathrm{O}$ value of modern meteoric water over Arctic Canada is $-20 \%$ (SMOW), while the value for precipitation over the centre of the Greenland Ice Sheet is $-35 \%$ (SMOW) (Dansgaard and Tauber, 1969). Therefore, the calcite $\delta^{18} \mathrm{O}$ values suggest a non-marine origin for the diagenetic concretions precipitated from a mixture of high-latitude meteoric water and ${ }^{18} \mathrm{O}$-depleted glacial melt water. The centre to rim gradients in the $\delta^{18} \mathrm{O}$ values observed in the concretions (Fig. 11) may reflect changes in temperature or in the proportion of meteoric to glacial melt water during the growth of the concretions. Variations in the centre to rim gradients may indicate either concentric or more complex, non concentric concretionary growth (Mozley, 1996).

The other possible explanation for the depleted $\delta^{18} \mathrm{O}$ values of the calcite, assuming the concretions precipitated from waters similar to Permo-Carboniferous seawater of $-2 \%$ (SMOW) (Veizer et al., 1997), is recrystallisation of the calcite at a temperature of approximately $170{ }^{\circ} \mathrm{C}$. Temperatures of $170{ }^{\circ} \mathrm{C}$ may have been reached in the Dwyka Group considering the proximity of the study area to the Cape Fold Belt (Daly et al., 1992) and the maximum burial depths of the Dwyka Group (Rubidge, 1995). However, regional metamorphic recrystallisation is expected to result in more uniform oxygen and, in particular, carbon isotopic trends than are observed in these concretions (Fig. 11). The lack of detrital grain replacement or calcite recrystallisation (aside from the vein calcite which has a significantly lower oxygen isotope value), also strongly suggests that the $\delta^{18} \mathrm{O}$ values are unaltered.

The negative $\delta^{13} \mathrm{C}$ values of the calcite concretions, with a mean value of $-12.3 \%$ o (PDB), indicate that carbon was largely derived from a strongly depleted ${ }^{13} \mathrm{C}$ source, most likely the microbial degradation of organic matter (Ehleringer, 1989). Abiotic marine calcite cements of early Permian age have $\delta^{13} \mathrm{C}$ values of between +3.5 and $+4.5 \%$ (PDB) (Lohmann and Walker, 1989). The range in $\delta^{13} \mathrm{C}$ values of -3 to $-16 \%$ (PDB) for Dwyka calcite concretions from this study overlap 
Sample Cross sections

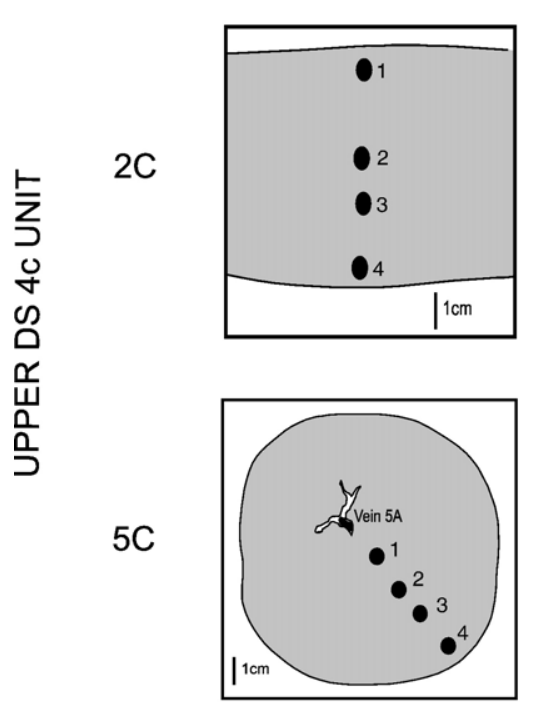

BD
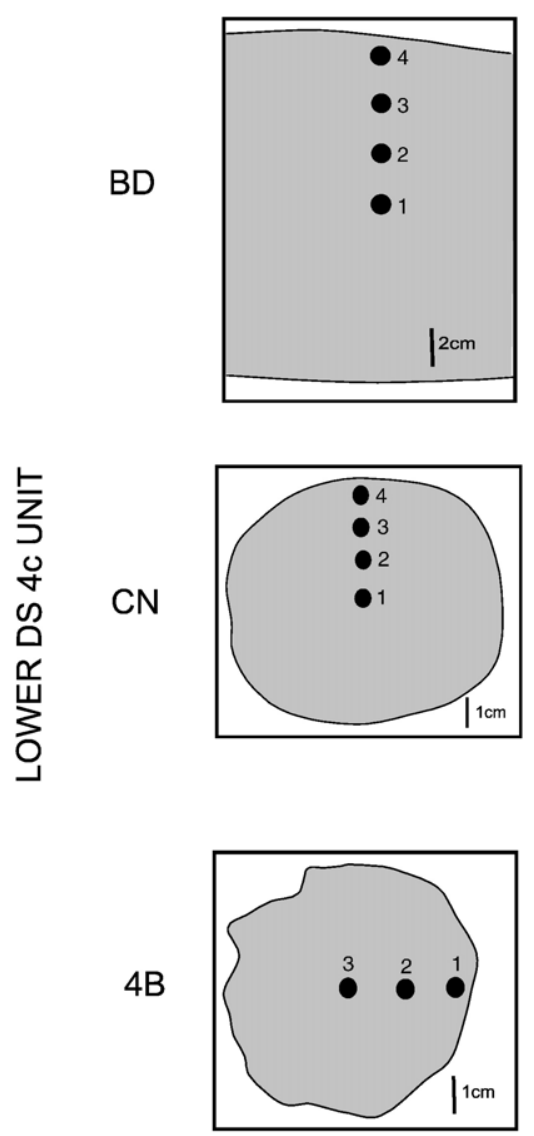
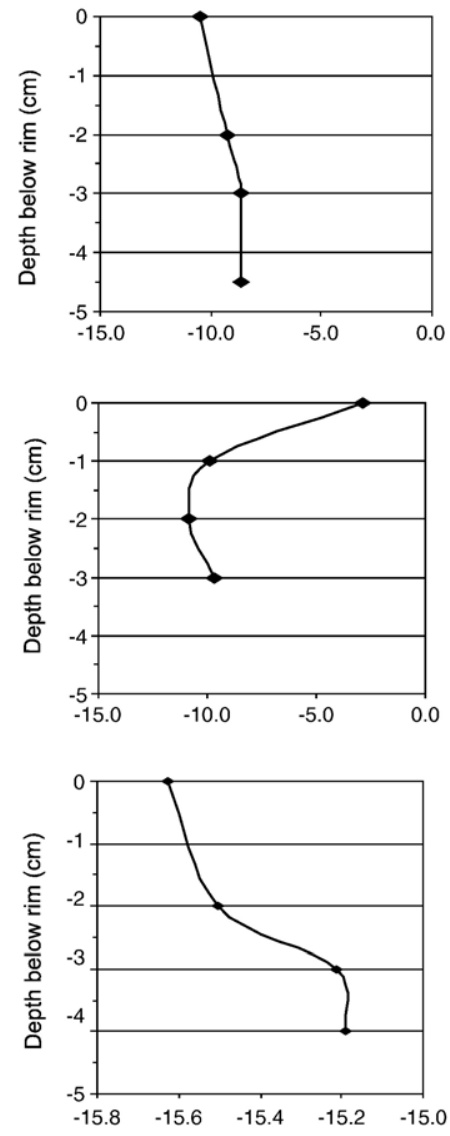

$\delta^{13} \mathrm{C}$ (PDB)
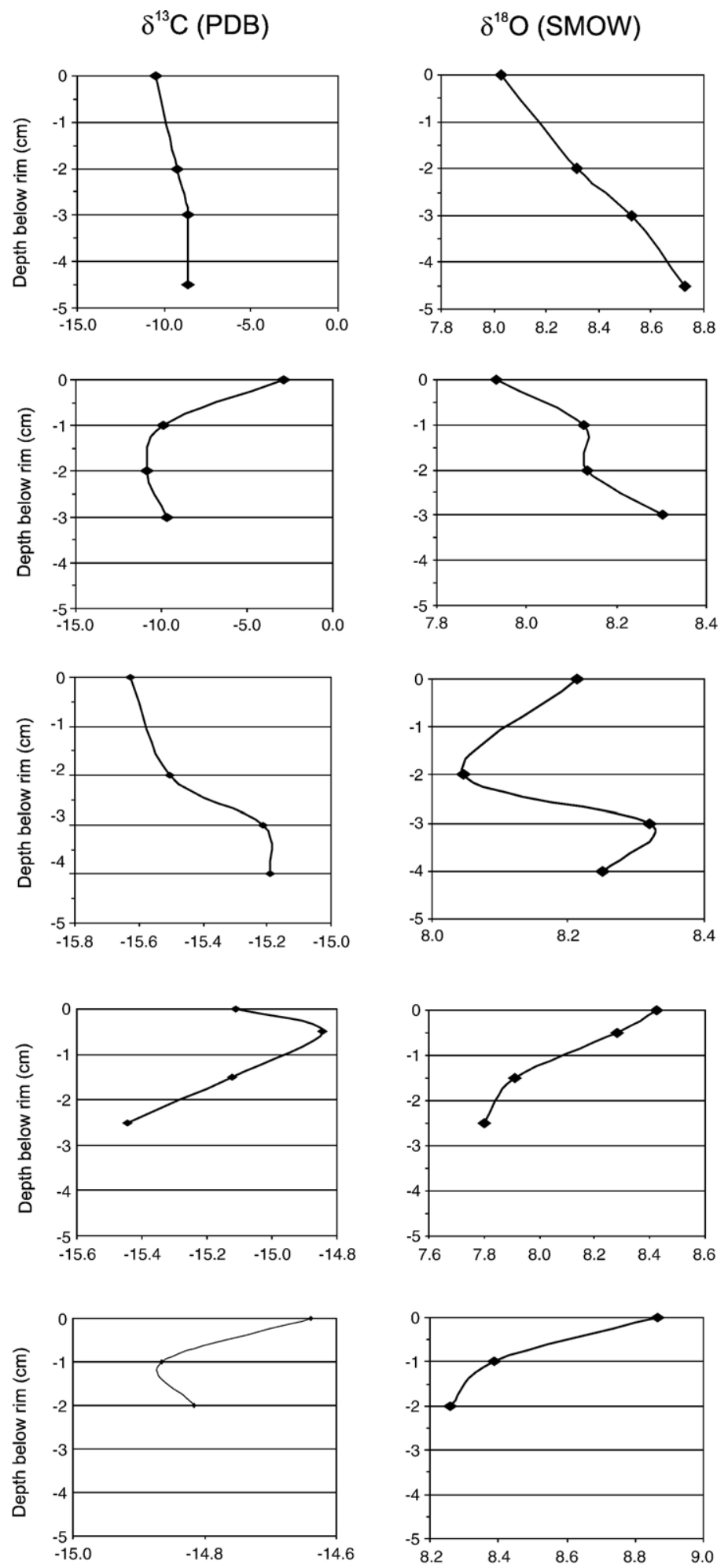

Fig. 11. Sketches of the interior cross sections of the concretion sub-sample locations, with the trends in $\delta^{13} \mathrm{C}$ and $\delta^{18} \mathrm{O}$ from the core/base to the rim/ top of the concretion. 


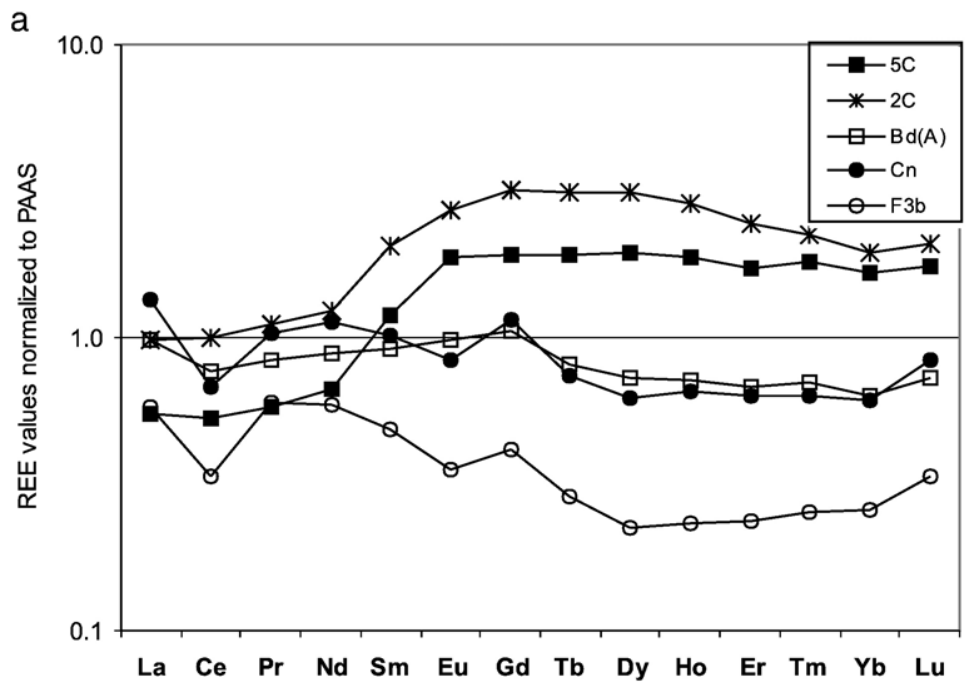

b

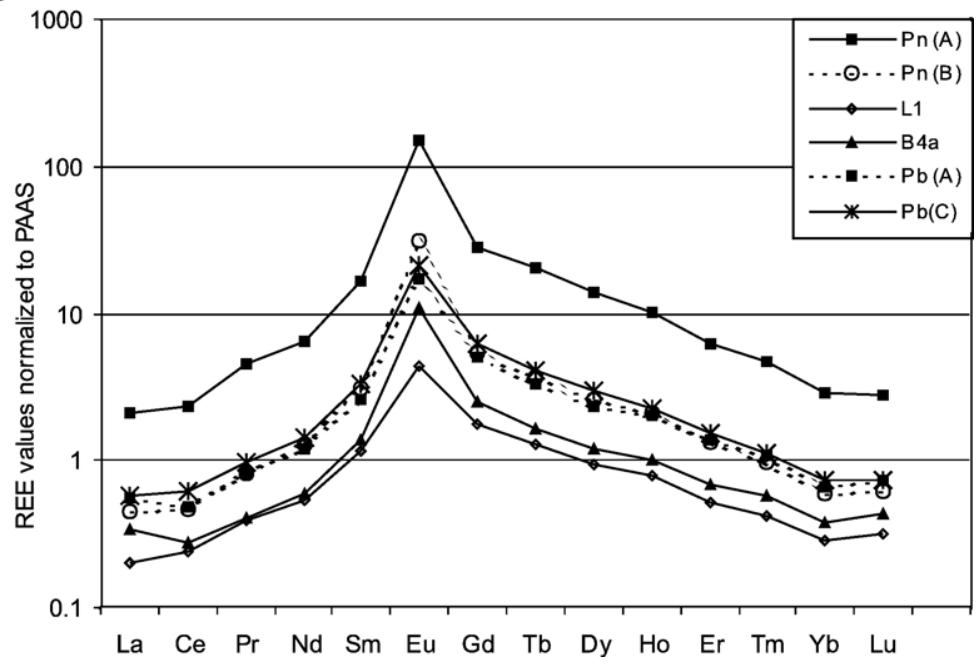

Fig. 12. a, The REE patterns of calcite cement from concretions in the lower (Cn and Bd (A) and upper (2C and 5C) DS 4c diamictite units of the Dwyka Group. The REE pattern of the disseminated calcite in the host diamictite of the lower DS 4c unit is also included (F3b). b, The REE patterns of the carbonate-fluorapatite cement of the phosphatic concretions and beds in the Prince Albert Formation.

with the $\delta^{13} \mathrm{C}$ value of carbonate in the upper Prince Albert Formation of $-16 \%$ (PDB) (Faure and Cole, 1999). The centre to rim $\delta^{13} \mathrm{C}$ gradients, particularly in sample 5C (Fig. 11), may indicate that the concretions formed in the lower sulphate-reduction zone to the top of the methanogenesis zone (Claypool and Kaplan, 1974; Middleton and Nelson, 1996). The presence of pyrite framboids in the Prince Albert Formation is consistent with precipitation in or below the sulphate-reduction zone and the only minor to trace amount of pyrite is consistent with a non-marine depositional environment.

The concretions are believed to have formed primarily during early burial diagenesis of the diamictite, deduced, in part from the trends in the $\delta^{13} \mathrm{C}$ values discussed above and in part from textural evidence. The depth of the sulphate-reduction and methanogenesis zones in which these concretions grew depends to a large extent on the organic matter content of the sediment, but these microbial zones are usually associated with early diagenesis over a burial range of tens of meters and possibly extended to depths of several hundred meters (e.g., Compton, 1988). The spherical shape of many of the Dwyka DS 4c calcite concretions and Prince Albert Formation phosphatic chert concretions suggests that they formed during early diagenesis (Seilacher, 2001) as does the greater amount of calcite cement in the concretions than in the host diamictite 
(Pratt, 2001). However, because of the massive nature of the host diamictite, sedimentary structures due to differential compaction were not observed. The increase in detrital grains from centre to rim also suggests cementation that occurred during sediment compaction, assuming concentric cementation (Mozley, 1996). The only slight decrease in calcite content from centre to rim in the DS $4 c$ concretions suggests that some concretion growth occurred in a complex manner, perhaps by the coalescing of individual micro concretions (Raiswell and Fisher, 2000). For example, sand-sized CFA concretions are observed in the Prince Albert Formation phosphatic chert concretions. The septarian cracks in the spherical calcite concretions from the upper Dwyka are interpreted to have formed while the interior of the concretions was still soft and not yet fully cemented (Pratt, 2001). Equally plausible mechanisms of septarian crack formation include chemical dehydration, rapid changes in overburden pressures (Seilacher, 2001) or syndepositional seismicity (Morad and Eshete, 1990; Pratt, 2001).

The ${ }^{87} \mathrm{Sr} /{ }^{86} \mathrm{Sr}$ ratios of the concretion cements are all significantly higher than that of Permo-Carboniferous seawater (0.707 to 0.708) (Popp et al., 1986) and indicate a radiogenic, cratonic source for the $\mathrm{Sr}$ (Burke et al., 1982; Palmer and Edmond, 1992). Glacial melt water is typically high in radiogenic Sr derived from the rapid weathering of fine grained (glacial flour) cratonic basement rocks (Palmer and Edmond, 1992; Anderson et al., 1997; Armstrong, 1971). The high Sr content of the calcite and CFA cements (Table 1) and their preferential dissolution by acetic acid, minimize the influence of radiogenic $\mathrm{Sr}$ leached from other minerals on the measured ratios. However, the unusually high ${ }^{87} \mathrm{Sr} /{ }^{86} \mathrm{Sr}$ ratio of sample BD (0.737) reflects the total digestion of this sample, including detrital clay minerals. The ${ }^{87} \mathrm{Sr} /{ }^{86} \mathrm{Sr}$ ratio of the present-day Orange River is approximately $0.715-0.717$ (Palmer and Edmond, 1989; de Villiers et al., 2000) and is similar to many of the values obtained for the concretions analysed (Table 2). This result is consistent with the fact that the Orange River and its tributaries today drain many of the pre-Karoo Archean cratonic and Proterozoic basement rocks over which the Dwyka Ice Sheet spread.

The REE patterns of calcite and CFA cements (Fig. 12) are equivocal and can be interpreted to reflect either sea water or river water signatures. Samples F3b, CN and BD show negative cerium anomalies and overall flat REE patterns (Fig. 12a) usually associated with precipitation in an oxidizing, seawater environment (McArthur and Walsh, 1984/1985), although some present-day rivers do have "seawater-like" REE patterns (Goldstein and Jacobsen, 1988; Elderfield et al., 1990). The relative HREE depletion exhibited by the samples, uncharacter- istic of Mesozoic or Cenozoic seawater patterns (McArthur and Walsh, 1984/1985; Ilyin, 1998), may also indicate alteration during weathering (McArthur and Walsh, 1984/1985; Shields and Stille, 2001). The MREE enrichment of calcite concretions from the upper diamictite unit DS 4c and, to a greater extent, of phosphatic samples from the Prince Albert Formation is often associated with river water (Hannigan and Sholkovitz, 2001). Alternatively, the MREE enrichment may reflect preferential uptake by organic matter transferred to the sediment as MREE-enriched faecal pellets and incorporated into phosphorite during early burial diagenesis (Kidder and Eddy-Dilek, 1994). The prominent positive $\mathrm{Eu}$ anomaly of phosphatic samples from the Prince Albert Formation may indicate CFA precipitation under reducing (anoxic) conditions (McArthur and Walsh, 1984/1985; Mazumdar et al., 1999).

\subsection{Proposed palaeoenvironmental evolution of the southwestern Karoo Basin}

The texture and geochemistry of calcite and phosphatic concretions presented above indicate that the concretions formed in a fresh, glacial melt water lake in the study area of the southwestern Karoo Basin. Deposition of massive diamictite reflects periods of maximum ice sheet extent when glacial till was deposited by subglacial ice sheet melting and by high density rain-out in a proximal environment (Visser, 1994a). We propose that the concretions formed in the massive diamictite deposits during periods of ice sheet retreat when large amounts of runoff supplied muddy glacial melt water and meteoric water to continental basins. In addition to dissolved carbonate and detrital rocks, these waters carried detrital organic matter (Alexander, 1999). Primary productivity in the lake may have also supplied significant organic matter to the sediments. The precipitation of calcite was promoted by warmer temperatures and the increase in carbonate alkalinity of the sediment pore waters associated with microbial degradation of buried organic matter in the sulphate-reduction and methanogenesis zones, as indicated by the negative $\delta^{13} \mathrm{C}$ values of the calcite (Compton, 1988). Melt waters were enriched in radiogenic $\mathrm{Sr}$ from the chemical weathering of fine grained calc-silicate rocks imparting to the calcite cement a more radiogenic Sr isotope ratio than Permian seawater.

Dated ash fall tuffs recovered from the Prince Albert Formation indicate deposition across the SakmarianArtinskian stage boundary (Fig. 2) (Bangert et al., 1999), which overlaps with the age proposed for the valleyhighland facies of the Dwyka Group (Visser, 1982; 1986; 1990). Therefore, while the Prince Albert Formation was 
deposited in the south, remnant glaciers of the Dwyka Ice Sheet persisted in the highlands to the north of the Karoo Basin. Phosphatic concretions of the lower Ecca Group formed similarly to the calcite concretions of the underlying Dwyka diamictites. However, the abundance of phosphatic concretions suggests that organic matter burial increased in the glacial melt water lake sediments during deposition of the lower Ecca Group.

\section{Conclusions}

The texture, low $\delta^{18} \mathrm{O}$ values and radiogenic Sr isotope ratios of early diagenetic calcite concretions of the DS 4c unit of the Dwyka Group diamictite and phosphatic chert concretions of the Prince Albert shale provide additional insight into the depositional setting of Gondwana at the close of the Permo-Carboniferous Ice Age. Although the prevailing view has been that the Dwyka Tillite represents a subaqueous marine glacial deposit (Visser, 1986, 1991, 1994b), here we present geochemical evidence from the southwestern Karoo Basin of South Africa that indicates Dwyka deposition occurred in a meteoric-glacial melt water lake. Similar geochemical evidence has been found from Gondwana glacial deposits in the eastern and southern Karoo Basin and on the Indian continent, suggesting that perhaps glaciolacustrine environments were widespread features on Gondwana during final deglaciation. The strongest evidence of a fresh water origin for the concretions is the depleted oxygen isotope composition of their calcite cement. The negative $\delta^{13} \mathrm{C}$ values suggest that the calcite cement formed as a result of microbial degradation of organic matter in the sulphate-reduction and methanogenesis zones of the massive diamictite at sediment depths of tens of meters up to several hundred meters. The textures and distinct isotopic trends that vary both within and among concretions from different stratigraphic horizons suggest that the isotopic values of the concretions have not been reset by later stage alteration or recrystallisation. The $\mathrm{Sr}$ isotope values obtained for the CFA cements from phosphatic concretions of the lower Prince Albert Formation are similar to those of the underlying Dwyka calcite concretions and suggest that fresh water lake environments persisted during the deposition of these sediments. Although the REE patterns are largely equivocal, those obtained for the phosphatic concretions are consistent with high surface-water productivity (Faure and Cole, 1999).

\section{Acknowledgements}

Funding for this study is gratefully acknowledged from the National Research Foundation and the Univer- sity of Cape Town Research Council. Mr. J. Loock and Dr. J. Rogers are thanked for their assistance in locating suitable sampling sites and Prof. C. Harris is thanked for running the oxygen and carbon isotope analyses. The manuscript benefited from constructive reviews by Peter Mozley and an anonymous reviewer.

\section{References}

Alexander, J., 1999. Carbon isotope stratigraphy of Permo-Carboniferous sediments in the Karoo Basin, south east of Laingsburg, South Africa. Unpublished Honours project, Department of Geological Sciences, University of Cape Town, Cape Town, South Africa, pp. 37.

Anderson, A., 1970. An analysis of supposed fish trails from interglacial sediments in the Dwyka Series, near Vryheid, Natal. Proceedings Gondwana Symposium 1970, 637-647.

Anderson, T.F, Arthur, M.A., 1983. Stable isotopes of oxygen and carbon and their application to sedimentologic and environmental problems. In: Arthur, M.A., Anderson, T.F., Kaplan, I.R., Veizer, J., Land, L.S. (Eds.), Stable Isotopes in Sedimentary Geology SEPM. Short Course Notes, vol. 10, pp. 1-151.

Anderson, S.P., Drever, J.I., Humphrey, N.F., 1997. Chemical weathering in glacial environments. Geology 25 (5), 399-402.

Armstrong, R.L., 1971. Glacial erosion and the variable isotopic composition of strontium in sea water. Nature Physical Science 230, 132-133.

Bangert, B., Stollhofen, H., Lorenz, V., Armstrong, R., 1999. The geochronology and significance of ash-fall tuffs in the glaciogenic Carboniferous-Permian Dwyka Group of Namibia and South Africa. Journal of African Earth Sciences 29 (1), 33-49.

Bhattacharya, S.K., Ghosh, P., Chakrabarti, A., 2002. Isotopic analysis of Permo-Carboniferous Talchir sediments from East-Central India: signature of glacial melt-water lakes. Chemical Geology 188, 261-274.

Buhmann, D., Buhmann, C., von Brunn, V., 1989. Glaciogenic banded phosphorites from Permian sedimentary rocks. Bulletin of the Society of Economic Geologists 48 (4), 741-750.

Bumby, A.J., Guiraud, R., 2005. The geodynamic setting of the Phanerozoic basins of Africa. Journal of African Earth Sciences 43, 1-12.

Burke, W.H., Denison, R.E., Hetherington, E.A., Koepnick, R.B., Nelson, H.F., Otto, J.B., 1982. Variation of seawater ${ }^{87} \mathrm{Sr} /{ }^{86} \mathrm{Sr}$ throughout Phanerozoic time. Geology 10, 516-519.

Catuneanu, O., Hancox, P.J., Rubidge, B.S., 1998. Reciprocal flexural behaviour and contrasting stratigraphies: a new basin development model for the Karoo retroarc foreland system, South Africa. Basin Research 10, 417-439.

Catuneanu, O., Hancox, P.J., Cairncross, B., Rubidge, B.S., 2002. Foredeep submarine fans and forebulge deltas: orogenic offloading in the underfilled Karoo Basin. Journal of African Earth Sciences 35, 489-502.

Claypool, G.E., Kaplan, I.R., 1974. The origin and distribution of methane in marine sediments. In: Kaplan, I.R. (Ed.), Natural Gases in Marine Sediments. Plenum Press, New York, pp. 99-140.

Cole, D.I., Smith, R.M.H., Wickens, H. de V., 1990. Basin-plain to fluvio-lacustrine deposits in the Permian Ecca and Lower Beaufort Groups of the Karoo Sequence. Guidebook Geocongress ' 90 Geological Society of South Africa, vol. PO2, pp. 1-83. 
Compton, J.S., 1988. Degree of supersaturation and precipitation of organogenic dolomite. Geology 16, 318-321.

Daly, M.C., Lawrence, S.R., Diemu-Tshiband, K., Matouana, B., 1992. Tectonic evolution of Cuvette Centrale, Zaire. Journal of the Geological Society (London) 149, 539-546.

Dansgaard, W., Tauber, H., 1969. Glacier oxygen-18 content and Pleistocene ocean temperatures. Science 166, 499-502.

de Swart, A.M.J., Rowsell, D.M., 1974. Note on the relationship between diagenesis and deformation in the Cape Fold Belt. Transactions of the Geological Society of South Africa 77, 239-245.

de Villiers, S., Compton, J.S., Lavelle, M., 2000. The strontium isotope systematics of the Orange River, Southern Africa. South African Journal of Geology 103, 237-248.

Domack, E.W., 1983. Facies of late Pleistocene glacial-marine sediments on Whidbey Island, Washington. In: Molnia, B.F. (Ed.), Glacial-marine Sedimentation. Plenum Press, New York, pp. $535-570$.

Ehleringer, J.R., 1989. Carbon isotope ratios and physiological processes in arid land plants. In: Rudel, P.W., Ehleringer, J.R., Nagy, K.A. (Eds.), Applications of Stable Isotopic Ratios to Ecological Research. Springer, New York.

Elderfield, H., Upstill-Goddard, R., Sholkovitz, E.R., 1990. The rare earth elements in rivers, estuaries, and coastal seas and their significance to the composition of ocean waters. Geochimica et Cosmochimica Acta 54, 971-991.

Faure, K., Cole, D.I., 1999. Geochemical evidence for lacustrine microbial blooms in the vast Permian Main Karoo, Paraná, Falkland Islands and Huab basins of southwestern Gondwana. Palaeogeography, Palaeoclimatology, Palaeoecology 152 (3/4), 189-213.

Faure, K., Harris, C., Willis, J.P., 1995. A profound meteoric water influence on the genesis in the Permian Waterberg Coalfield, South Africa: evidence from stable isotopes. Journal of Sedimentary Research 65 (4), 605-613.

Goldstein, S.J., Jacobsen, S.B., 1988. Rare earth elements in river waters. Earth and Planetary Science Letters 89, 35-47.

Gradstein, F., Ogg, J., Smith, A. (Eds), 2004. A Geological Timescale 2004. Cambridge University Press, Cambridge, p. 589.

Hannigan, R.E., Sholkovitz, E.R., 2001. The development of middle rare earth element enrichments in freshwaters: weathering of phosphate minerals. Chemical Geology 175, 495-508.

Ilyin, A.V., 1998. Rare-earth geochemistry of 'old' phosphorites and probability of syngenetic precipitation and accumulation of phosphate. Chemical Geology 144, 243-256.

Kidder, D.L., Eddy-Dilek, C.A., 1994. Rare-earth element variation in phosphate nodules from mid-continent Pennsylvanian cyclothems. Journal of Sedimentary Research 64 (3), 584-592.

Lohmann, K.C., Walker, J.C.G., 1989. The $\delta^{18} \mathrm{O}$ record of Phanerozoic abiotic marine calcite cements. Geophysical Research Letters 8 (4), 319-322.

MacRae, C., 1999. Life etched in stone, fossils of South Africa. Geological Society of South Africa, Johannesburg. 305 pp.

Martin, H., Wilczewski, N., 1970. Palaeoecology, conditions of deposition and the palaeogeography of the marine Dwyka beds of South West Africa. Proceedings Gondwana Symposium 1970, pp. 225-232.

Mazumdar, A., Banerjee, D.M., Schidlowski, M., Balaram, V., 1999. Rare-earth elements and stable isotope geochemistry of early Cambrian chert-phosphorite assemblages from the Lower Tal Formation of the Krol Belt (Lesser Himalaya, India). Chemical Geology 156, 275-297.

McArthur, J.M., Walsh, J.N., 1984/1985. Rare-earth geochemistry of phosphorites. Chemical Geology 47, 191-220.
McLachlan, I.R., Anderson, A., 1973. A review of the evidence for marine conditions in Southern Africa during Dwyka times. Palaeontologia Africana 15, 37-64.

McLennan, S.M., 1989. Rare earth elements in sedimentary rocks: influence of provenance and sedimentary processes. In: Lippin, B.R., McKay, G.A. (Eds.), Reviews in Mineralogy. Geochemistry and Mineralogy of Rare Earth Elements, vol. 21. The Mineralogical Society of America, Washington, D.C., pp. 169-200.

Middleton, H.A., Nelson, C.S., 1996. Origin and timing of siderite and calcite concretions in late Palaeogene non- to marginal-marine facies of the Te Kuiti Group, New Zealand. Sedimentary Geology 103, 93-115.

Morad, S., Eshete, M., 1990. Petrology, chemistry and diagenesis of calcite concretions in Silurian shales from central Sweden. Sedimentary Geology 66, 113-134.

Mozley, P.S., 1996. The internal structure of carbonate concretions in mudrocks: a critical evaluation of the conventional concentric model of concretion growth. Sedimentary Geology 103, 85-91.

Oelofsen, B.W., 1986. A fossil shark neurocranium from the PermoCarboniferous (lowermost Ecca Formation) of South Africa. Proceedings of the 2nd International Conference of Indo-Pacific Fishes, Tokyo, pp. 107-124.

Opdyke, N.D., Mushayandebvu, M., de Wit, M.J., 2001. A new palaeomagnetic pole for the Dwyka System and correlative sediments in sub-Saharan Africa. Journal of African Earth Sciences 33 (1), 143-153.

Palmer, M.R., Edmond, J.M., 1989. The strontium isotope budget of the modern ocean. Earth and Planetary Science Letters 92, 11-26.

Palmer, M.R., Edmond, J.M., 1992. Controls over the strontium isotope composition of river water. Geochimica et Cosmochimica Acta 56, 2099-2111.

Popp, B.N., Podosek, F.A., Brannon, J.C., Anderson, T.F., Pier, J., 1986. ${ }^{87} \mathrm{Sr} /{ }^{86} \mathrm{Sr}$ ratios in Permo-Carboniferous seawater from the analyses of well-preserved brachiopod shells. Geochimica et Cosmochimica Acta 50, 1321-1328.

Pratt, B.R., 2001. Septarian concretions: internal cracking caused by synsedimentary earthquakes. Sedimentology 48, 189-213.

Raiswell, R., Fisher, Q.J., 2000. Mudrock-hosted carbonate concretions: a review of growth mechanisms and their influence of chemical and isotopic composition. Journal of the Geological Society (London) 157, 239-251.

Rubidge, B.S., 1995. Biostratigraphy of the Beaufort Group (Karoo Supergroup). South African Committee for Stratigraphy, Biostratigraphic series, vol. 1. Council for Geoscience, Pretoria, p. 46.

Savage, N.M., 1970. A preliminary note on arthropod trace fossils from the Dwyka Series in Natal. Proceedings Gondwana Symposium, 1970, pp. 627-635.

Seilacher, A., 2001. Concretion morphologies reflecting diagenetic and epigenetic pathways. Sedimentary Geology 143, 41-57.

Shields, G., Stille, P., 2001. Diagenetic constraints on the use of cerium anomalies as palaeoseawater redox proxies: an isotopic and REE study of Cambrian phosphorites. Chemical Geology 175, 29-48.

Smith, N.D., Ashley, G., 1985. Proglacial lacustrine environment. In: Ashley, G.M., Shaw, J., Smith, N.D. (Eds.), Glacial Sedimentary Environments SEPM Short Course, vol. 16, pp. 135-216.

Strydom, H.C., 1950. The geology and chemistry of the Laingsburg phosphorites: Annales of the University of Stellenbosch, vol. 26A, pp. 267-285.

Tankard, A.J., Jackson, M.P.A., Eriksson, K.A., Hobday, D.K., Hunter, D.R., Minter, W.E.L., 1982. Crustal Evolution of Southern Africa. Springer-Verlag, New York, pp. 1-523. 
Theron, J.N., Blignault, H.J., 1975. A model for the sedimentation of the Dwyka Glacials in the Southwestern Cape. In: Campbell, R.S.W. (Ed.), Gondwana Geology. University Press, Canberra, pp. 347-356. Veevers, J.J., Powell, C.McA., 1987. Late Paleozoic glacial episodes in Gondwanaland reflected in transgressive-regressive depositional sequences in Euramerica. Bulletin of the Geological Society of America 98, 475-487.

Veizer, J., Bruckschen, P., Pawelleck, F., Diener, A., Podlaha, O.G., Jasper, T., Korte, C., Carden, G.A.F., Strauss, M., Azmy, K., Ala, D., 1997. Oxygen isotope evolution of Phanerozoic seawater. Palaeogeography, Palaeoclimatology, Palaeoecology 132, 159-172.

Visser, J.N.J., 1982. Implications of a diachronous contact between the Dwyka Formation and the Ecca Group in the Karoo Basin. South African Journal of Science 78, 249-251.

Visser, J.N.J., 1986. Lateral lithofacies relationships in the glacigene Dwyka Formation in the western and central parts of the Karoo Basin. Transactions of the Geological Society of South Africa 89, 373-383.

Visser, J.N.J., 1989. The Permo-Carboniferous Dwyka Formation of Southern Africa: deposition by a predominantly subpolar marine ice sheet. Palaeogeography, Palaeoclimatology, Palaeoecology 70, 377-391.

Visser, J.N.J., 1990. The age of the late Palaeozoic glacigene deposits in southern Africa. South African Journal of Geology 93 (2), $366-375$.
Visser, J.N.J., 1991. Self-destructive collapse of the Permo-Carboniferous marine ice sheet in the Karoo Basin: evidence from the southern Karoo. South African Journal of Geology 94, 255-262.

Visser, J.N.J., 1993. A reconstruction of the Late Palaeozoic ice sheet on southwestern Gondwana. In: Findlay, Unrug, Banks, Veevers (Eds.), Balkema, Rotterdam, Gondwana Eight, pp. 449-458.

Visser, J.N.J., 1994a. The interpretation of massive rain-out and debris-flow diamictites from the glacial marine environment. In: Deynoux, M., Miller, J.M.G, Domack, E.W., Eyles, N., Fairchild, I.J., Young, G.M. (Eds.), Earth's Glacial Record. International Geological Correlation Project, vol. 260. Cambridge University Press, Cambridge, pp. 83-94.

Visser, J.N.J., 1994b. A Permian argillaceous syn- to post-glacial foreland sequence in the Karoo Basin, South Africa. In: Deynoux, M., Miller, J.M.G, Domack, E.W., Eyles, N., Fairchild, I.J., Young, G.M. (Eds.), Earth's Glacial Record. International Geological Correlation Project, vol. 260. Cambridge University Press, Cambridge, pp. 193-203.

Visser, J.N.J., Loock, J.C., 1987. Ice margin influence on glaciomarine sedimentation in the Permo-Carboniferous Dwyka Formation from the southwestern Karoo, South Africa. Sedimentology 34, 929-941. 